\title{
Continuous Sorption of Chromium Ions from Simulated Effluents using Citric Acid Modified Sweet Potato Peels
}

\author{
M. D. Yahya ${ }^{1 *}$, C. V. Ihejirika ${ }^{1}$, Y. A. Iyaka ${ }^{2}$, U. Garba ${ }^{3}$, A. G. Olugbenga ${ }^{1}$ \\ ${ }^{1}$ Department of Chemical Engineering, Federal University of Technology, Minna, Nigeria. \\ ${ }^{2}$ Department of Chemistry, Federal University of Technology, Minna, Nigeria. \\ ${ }^{3}$ Department of Mechanical Engineering, Faculty of Engineering and Environmental Design, \\ Usmanu Danfodiyo University Sokoto, Sokoto State, Nigeria.
}

\begin{abstract}
Adsorptive removal of chromium ion in aqueous medium using activated sweet potato peel (SPP) was studied in a laboratory-scale fixed bed column. Specifically, the effect of process parameters such as bed depth, flowrate and chromium ion concentration in aqueous solution, on the adsorption efficiency of the acid modified sweet potato peel was examined. Column adsorption analysis showed that at the flow rate of $0.5 \mathrm{~cm}^{3} / \mathrm{min}$, bed height of $6 \mathrm{~cm}$ and column influent concentration of $30 \mathrm{mg} / \mathrm{dm}^{3}$, the optimum chromium (VI) ion removal of $87.5 \%$ was attained with the equilibrium adsorption capacity of $2.4548 \mathrm{mg} / \mathrm{g}$. Continuous adsorption models such as Yoon-Nelson, Adam-Bohart and the Bed-Depth Service Time (BDST) model, were used to analyse the experimental data and based on correlation coefficient, BDST model best aligned with the obtained experimental data with correlation coefficient, $\mathrm{R}^{2}$, value of $96.43 \%$. The bed capacity, $\mathrm{N}_{\mathrm{o}}$, and the rate constant, $\mathrm{K}_{\mathrm{a}}$, were calculated as $4.259 \mathrm{mg} / \mathrm{dm}^{3}$ and $0.01045 \mathrm{~L} / \mathrm{mgmin}$ respectively at optimum column conditions. Results confirmed that acid modified SPP can be used to remove or reduce concentrations of $\mathrm{Cr}$ (VI) ions to allowable limits before disposal into water bodies.
\end{abstract}

KEYWORDS: Continuous sorption, chromium ions, sweet potato peel, kinetic isotherms, breakthrough curves

[Received July 6, 2019, Revised September 12, 2019, Accepted February 22, 2020]

Print ISSN: 0189-9546 | Online ISSN: 2437-2110

\section{INTRODUCTION}

In recent times, heavy metal pollution mostly due to industrialisation has become one of the most serious environmental problems in developing countries such as Nigeria. The discharge wastewater resulting from industrial processes has indicated high levels of heavy metals which, even in trace quantities, are toxic, have high potential threats to air, water and soil as well as bioaccumulation throughout the food chain and finally affect human beings (Alok et al., 2015). The recommended threshold limit value of $\mathrm{Cr}$ (VI) ions before it is discharged into receiving water bodies is 0.1 $\mathrm{mg} / \mathrm{dm}^{3}$ (Blanes et al., 2016). Cr (VI) ions enters the environment as a result of various industrial activities such as tannery, metal fishing, inorganic chemicals production, steel manufacturing and electroplating which make use of chromium or its compounds in its production. It is rapidly absorbed into the bloodstream and have adverse effects to major organs, causing ill health such as hypersensitive reactions, rashes on skin, irritations, bleeding through nostrils, weakened immune system, alteration of genetic material, kidney and liver impairment and most likely results to death

*Corresponding author: muibat.yahya @ futminna.edu.ng of the individual (Podder et al. 2016; Ahmad and Haydar, 2016).

Several methods have been employed to remove ions of heavy metal from the effluent of industries before it is discharged into the environment. Farooq et al., (2010) lists out methods such as ion exchange, chemical precipitation, coagulation, phytoremediation, electrolysis and reverse osmosis as some of the effective means of removing or reducing the concentration of heavy metal ions from aqueous solution. Although these methods can achieve tremendous positive result when employed on a lab scale analysis, they have proven to be inefficient, ineffective or uneconomical for use in the treatment of large quantity of contaminated effluents Farooq et al., (2010).

Due to the recognised bioaccumulation nature of heavy metals and its nocuous tendency on living organisms, even in relatively small amount, it has become a necessity to explore highly efficient and economical way of treating solutions containing these ions (Fernanda et al., 2016). Adsorption is one of the conventional and prolific methods employed for the treatment of large volume of solutions contaminated with heavy metals ion (Shalaby et al., 2016). The major advantages 
of adsorption over other conventional methods of treatment are low cost of adsorbent/adsorbent materials, flexibility of operation and design, high efficiency, regeneration of adsorbent, simplicity and possibility of adsorbate ion/molecule recovery (Amosa et al., 2015).

The adsorption potential and capacity of several agriculturally based biosorbents such as orange peels, rice husk, neem seed, ficus carcia leaves, tamarack bark, cotton seed hulls, have reportedly been investigated for the removal of heavy metals. The results confirmed that biosorbents are highly effective for removal of ions from heavy metals-laden wastewaters due to their porosity and presence of multifunctional groups such as - $\mathrm{OH}-,-\mathrm{COOH}-,-\mathrm{NH}_{2}$ - on their surfaces (Ahmad et al., 2015).

Sweet potato (Ipomoea Batatas) is wildly grown in Nigeria and has been on an increase from 28000 hectares in 1990 to 933500 hectares in 2010 (Kathryn et al., 2012). Making Nigeria the third world producer with an annual production of 3.46 million metric tons. Its peels which are readily available, cheap and environmentally friendly are considered as wastes. The use of sweet potato peels as an adsorbent in the adsorption of heavy metals has been advocated in recent years. Batch adsorption studies for the effective removal of heavy metals using sweet potato peel which includes the adsorption of $\mathrm{Fe}$ (III) ions (Prasad and Abdullah, 2009), removal of Ni (II) ions (Kakanlanga et al., 2012), removal of Cd (II) ions, (Okoro and Abii, 2011) have also been conducted by researchers. However, limited or no studies are available on the use of sweet potato peels for the removal of $\mathrm{Cr}$ (VI) ions. Therefore, this research work seeks to study the adsorption dynamics of $\mathrm{Cr}$ (VI) ions ion using acid modified sweet potato peel (SPP) in a continuous adsorption system.

\section{MATERIALS AND METHODS}

\section{A. Materials}

Sweet potato peels were obtained from local potato chips making unit in Gidan Kwano, Minna, Niger State, and Nigeria. Chemicals used for the research namely potassium dichromate $\left(\mathrm{K}_{2} \mathrm{Cr}_{2} \mathrm{O}_{7}\right)$ and citric acid were of analytical grade.

\section{B. Methods}

\section{1.) Sample preparation}

The sweet potato peel (SPP) collected was thoroughly washed with clean water to remove the earthly matter and all other dirt particles. This was then rinsed with deionized water to ensure neutrality of the precursor material and oven dried at 70-80oC for about 16 hours a temperature range and time when a constant weight of the SPP sample was attained and ensured most of the water was removed without decomposing the sample as recommended by Jones et al., (1991). The dried SPP was grounded and sieved to get a uniform adsorbent of size $350 \mu \mathrm{m}$. The SPP was placed in a plastic bottle container and kept in a desiccator before its use to preserve it and minimize contact with humidity.

\section{2.) Modification of the adsorbent}

The adsorbent was modified to enhaance the pore sizes using the method reported by $\mathrm{Lu}$ and Liang (2013). $10 \mathrm{~g}$ of unmodified SPP powder was added into $1.0 \mathrm{~mol} / \mathrm{dm}^{3}$ citric acid $\left(\mathrm{C}_{6} \mathrm{H}_{8} \mathrm{O}_{7}\right)$ solution $(70 \mathrm{ml})$ and the acid/powder slurry stirred for 30 minutes to mix completely and then dried without stirring for 12 hours at $50{ }^{\circ} \mathrm{C}$ and then further dried for 90 minutes at $120^{\circ} \mathrm{C}$. Thereafter, it was rinsed thoroughly to remove excess acid and finally dried at $75^{\circ} \mathrm{C}$ for 16 hours.

\section{3.) Preparation of reagent (solution)}

A stock solution of $1000 \mathrm{mg} / \mathrm{dm}^{3}$ of chromium (VI) ion was made by dissolving $2.828 \mathrm{~g}$ of potassium dichromate $\left(\mathrm{K}_{2} \mathrm{Cr}_{2} \mathrm{O}_{7}\right)$ in $1000 \mathrm{~cm}^{3}$ volumetric flask with distilled water and made up to mark. Serial dilutions were prepared from the stock.

\section{4.) Experimental methods}

Column adsorption studies were conducted using a tubular column of size $2.74 \mathrm{~cm}$ in diameter and $30 \mathrm{~cm}$ in height. Varying bed height of $2 \mathrm{~cm}, 4 \mathrm{~cm}$ and $6 \mathrm{~cm}$ were used in the experiment to examine the effect of bed height on the adsorption process. The column was charged with the stock solution in a downward flow mode using a peristaltic pump model Longer, BQ50-1J manufactured by Longer precision company, Beijing, China. The concentration of the solution charged into the column was varied $\left(5,15\right.$, and $\left.30 \mathrm{mg} / \mathrm{cm}^{3}\right)$ and the effect of flow rate was studied with varying flow rates of $0.5,1.5$ and $2 \mathrm{~cm}^{3} / \mathrm{min}$. The column was operated at sea level, and column internal pressure kept close to atmospheric pressure (Yahya and Odigure, 2015).

The aliquot was collected at 2-hour intervals, for 48 hours and then analysed using a PinAAcle Atomic Absorption Spectrophotometer model $900 \mathrm{H}$ manufactured by Perkin Elmer (USA) equipped with a combined flame/furnace system and continuum source background correction, was used to determine the instantaneous concentration of $\mathrm{Cr}$ (V1) ions in the downstream. The effect of bed height, flow rate and initial metal ion concentrations was studied. The optimum $\mathrm{pH}$ was taken after each sample was collected.

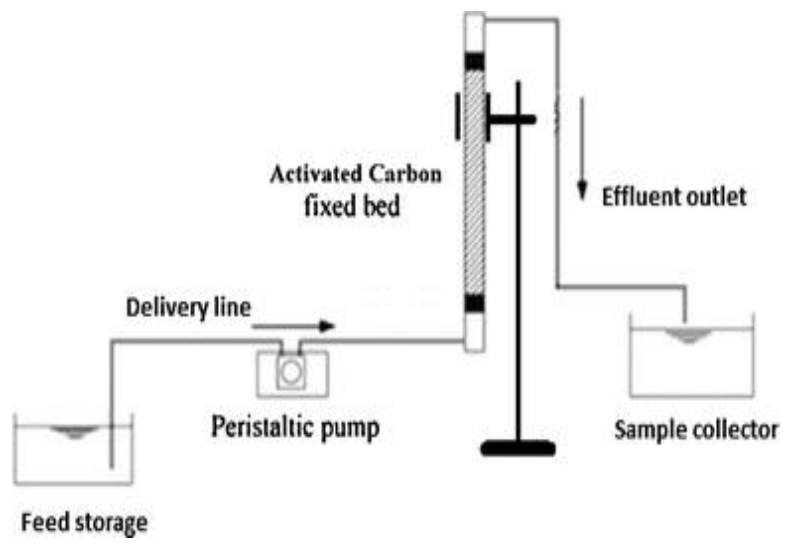

Figure1: Schematic diagram of the packed column. 


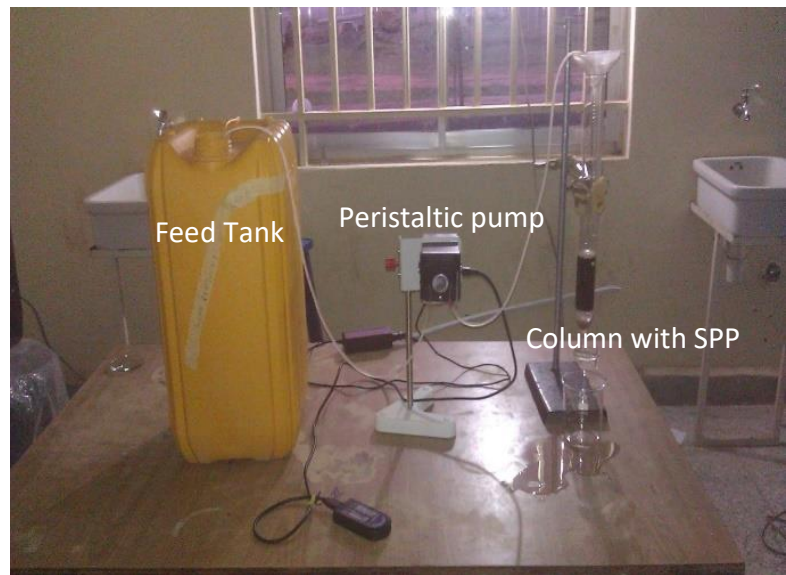

Plate 1: The packed column

\section{5.) Characterization of the raw and adsorbed SPP}

Both raw and adsorbed SPP were characterised using FourierTransform Infrared (FT-IR) spectrophotometer for the determination of functional groups responsible for the binding of the metal ions on the material. Scanning Electron Microscopy (SEM) test indicate the morphology, pores and cavities present at high resolution while the Energy Dispersive X-ray Analysis (EDAX) was also used to determine the elemental composition of the samples.

\section{6.) Fourier-transform infrared spectroscopy (FT-IR)}

FT-IR Spectrophotometer was used before and after adsorption process for the determination of the functional groups. The percentage transmittance was plotted against wave number at a range of $400-4000 \mathrm{~cm}^{-1}$. Raw sample FT-IR spectrum shown in Figure $2 \mathrm{a}$ indicated the major bands with peaks at range of 3420.12-3566.09 $\mathrm{cm}^{-1}$ indicating $\mathrm{O}-\mathrm{H}$ stretches and thus representing hydroxyl groups (Cozzolino et al., 2014). During adsorption of the $\mathrm{Cr}$ (VI) ions, peaks at 1376.74-1507.01 $\mathrm{cm}^{-1}$ as shown in Figure $2 \mathrm{~b}$ indicated spread out to several peaks, in the range of $1614.90-1738.29 \mathrm{~cm}^{-1}$.

This assignation corresponded to $\mathrm{C}=\mathrm{O}$ band stretch showing the presence of carboxylic acids or their esters groups as reported by Li et al. (2007) and Iqbal et al. (2009). Range of peaks from 1557.43-1634.11 $\mathrm{cm}^{-1}$ indicates the $\mathrm{N}-\mathrm{H}$ bend showing the primary amine groups while range from 1455.921538.64 $\mathrm{cm}^{-1}$ shows the secondary amine groups. Peak at $1014.03-1339.74 \mathrm{~cm}^{-1}$ shifted to $1033.07-1376.82 \mathrm{~cm}^{-}$ ${ }^{1}$ respectively indicating the presence of nitro groups while 1033.07, 721.36 and 422.93 shows $\mathrm{C}-\mathrm{O}$ stretch, $\mathrm{C}-\mathrm{Cl}$ stretch and $\mathrm{C}-\mathrm{Br}$ stretch respectively (Cozzolino et al., 2014; John, 2000). This could be attributed to the functional groups bonding with the metal ions. Studies have also indicated that the shifting of wave number depends on the concentration of the metal present in the given sample (Ushamary and Madhu, 2014). It can also be inferred from this study that several binding and chelating groups such as hydroxyl, carboxyl and the carbonyl groups could be responsible for the biosorption of $\mathrm{Cr}$ (VI) ions onto the surface of the SPP.

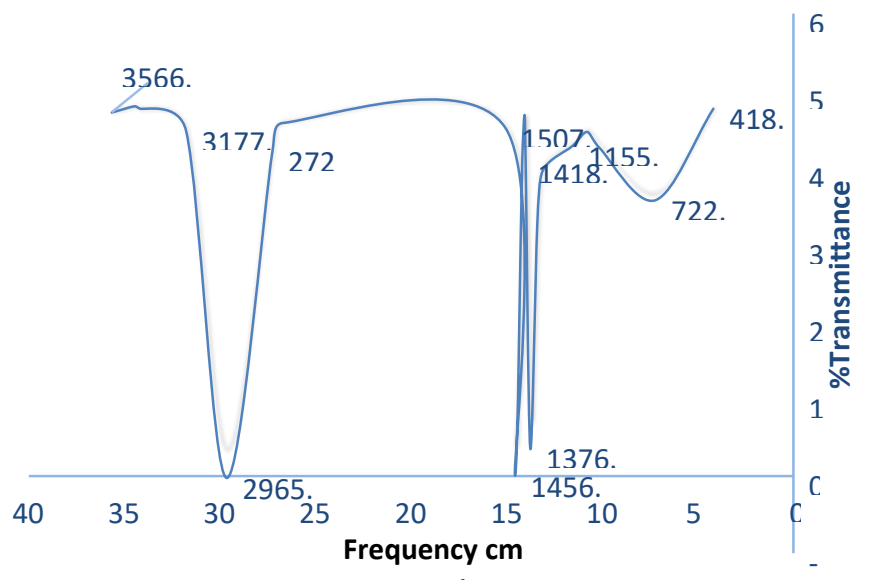

Figure 2a: FT-IR result for raw SPP.

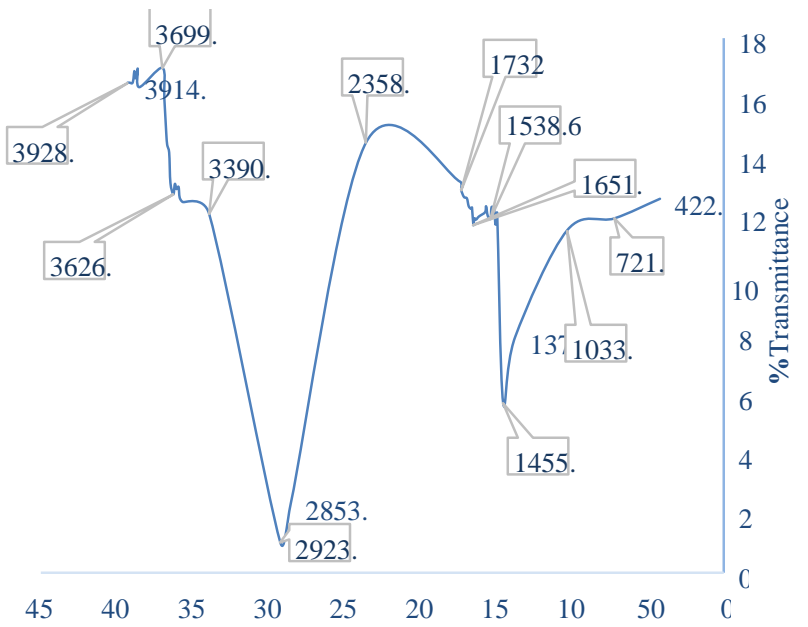

Frequency cm

Figure 2b: FT-IR result for SPP after adsorption.

7.) Scanning electron microscope analysis

The SEM image showed the morphological characteristic of the adsorbent before and after adsorption as shown in Figures $3 \mathrm{a}$ and $3 \mathrm{~b}$. This was carried out using SEM coupled with energy dispersive X-ray spectrometry of model JEOL JMT300 machine. The SEM micrograph of the original peels showed a surface morphology that is irregular and porous which implies high surface area capable of adsorbing the chromium ions. However, after the adsorption of $\mathrm{Cr}$ (VI) ions, the spherical irregular surface flattened out because of the relaxation of the SPP extracellular matrix that has captured the $\mathrm{Cr}$ (VI) ions. The X-ray energy dispersion analysis (EDAX) results (Figures $4 \mathrm{a}$ and $4 \mathrm{~b}$ ) revealed the emergence of the chromium ions after the adsorption process, high concentration of $\mathrm{K}$ and appearance of $\mathrm{Na}$ and $\mathrm{Si}$ which may be as a results of the change in the cell wall that consist of polysaccharides especially pectin (Blanes et al. 2016). 


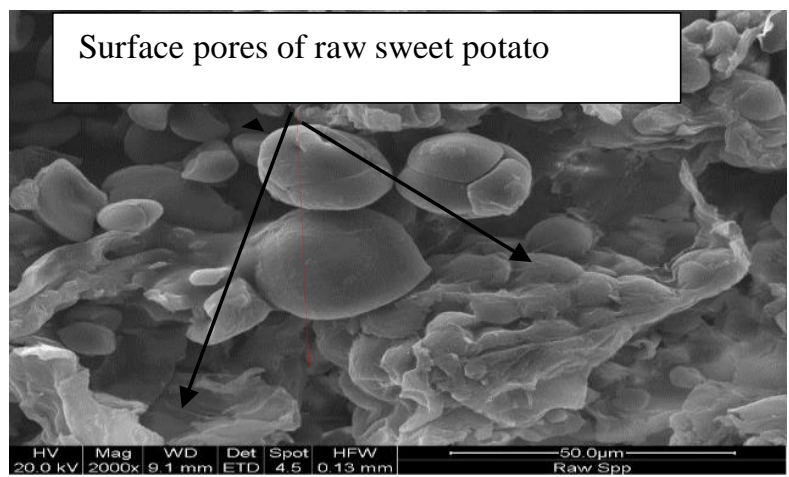

Figure 3a: Raw sweet potato

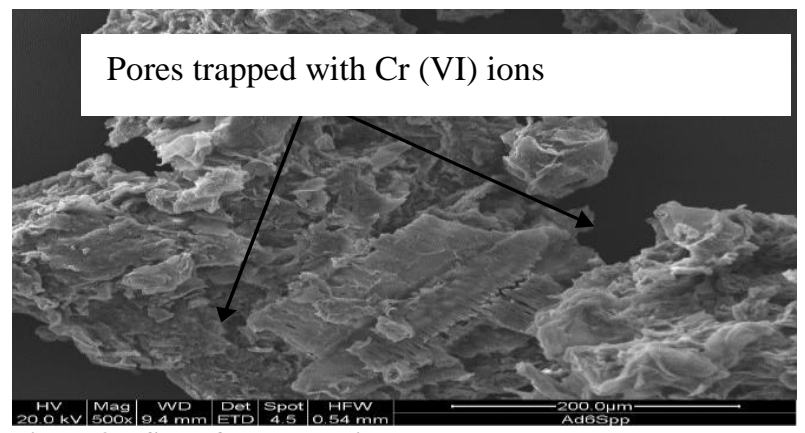

Figure 3b: SPP after adsorption.

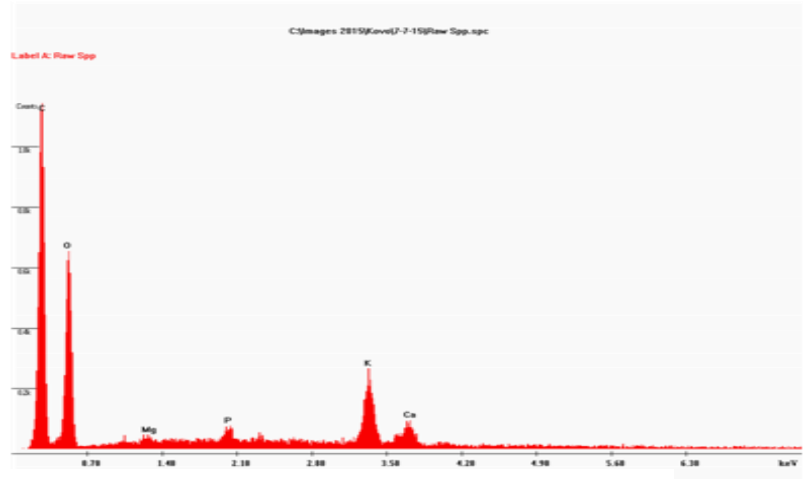

Figure 4a: EDAX for raw SPP.

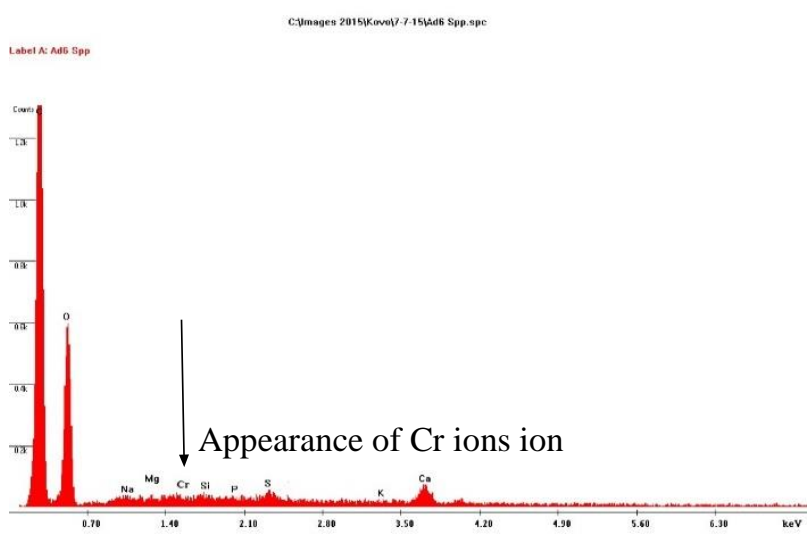

Figure 4b: EDAX for SPP after adsorption.

\section{RESUL'S AND DISCUSSION}

\section{A. Presentation of Results}

\section{A.1 Analysis of column data}

The results obtained from the analysis of the column data are presented in Table 1.
Table 1: Column Data Calculations

Parameters X $(\mathrm{g}) \mathrm{V}_{\text {eff }}(\mathrm{ml}) \mathrm{T}_{\text {total }}(\mathrm{min}) \operatorname{Area}\left(\mathrm{cm}^{2}\right) \mathrm{Q}_{\text {total }}(\mathrm{mg}) \quad \mathrm{M}_{\text {total }}(\mathrm{mg}) \quad \mathrm{Y} \% \mathrm{q}_{\mathrm{eq}}(\mathrm{mg} / \mathrm{g})$ Bed height $(\mathrm{cm})$ at fixed influent flow rate of $0.5 \mathrm{~cm}^{3} / \mathrm{min}$ and concentration of 5 $\mathrm{mg} / \mathrm{dm}^{3}$

$\begin{array}{ccccccccc}2 & 3.5 & 1440 & 2880 & 12174.96 & 6.0875 & 7.2 & 84.5 & 1.7393 \\ 4 & 7.3 & 1440 & 2880 & 12237.66 & 6.1188 & 7.2 & 84.9 & 0.8382 \\ 6 & 15.4 & 1440 & 2880 & 12340.80 & 6.1704 & 7.2 & 85.9 & 0.4007\end{array}$

Flowrate $\left(\mathrm{cm}^{3} / \mathrm{min}\right)$ at the fixed bed height of $6 \mathrm{~cm}$ and influent concentration of 5 $\mathrm{mg} / \mathrm{dm}^{3}$

$\begin{array}{ccccccccc}0.5 & 15.4 & 1440 & 2880 & 12340.80 & 6.1704 & 7.2 & 85.9 & 0.4007 \\ 1.5 & 15.4 & 3600 & 2400 & 9039.90 & 13.5599 & 18.0 & 75.3 & 0.8805 \\ 2.0 & 15.4 & 5280 & 2640 & 8904.90 & 17.8098 & 26.4 & 69.5 & 1.1564\end{array}$

Concentration $(\mathrm{mg} / \mathrm{dm} 3)$ at fixed bed height of $6 \mathrm{~cm}$ and influent flow rate of 0.5 $\mathrm{cm}^{3} / \mathrm{min}$

\begin{tabular}{ccccccccc}
5 & 15.4 & 1440 & 2880 & 12340.80 & 6.1704 & 7.2 & 85.9 & 0.4007 \\
15 & 15.4 & 1440 & 2880 & 37132.20 & 18.5661 & 21.6 & 86.0 & 1.2056 \\
30 & 15.4 & 1440 & 2880 & 75609.36 & 37.8047 & 43.2 & 87.5 & 2.4548 \\
\hline
\end{tabular}

\section{A.2 Effect of bed height}

Adsorption of metals in a column of fixed dimensions depends on the amount of adsorbent in the column. Figure 5a shows the plot of normalised concentration of $\mathrm{Cr}$ (VI) ions against time at varying bed heights of 2, 4 and $6 \mathrm{~cm}$ under a fixed flow rate of $0.5 \mathrm{~cm}^{3} / \mathrm{min}$ and at constant influent concentration of 5 $\mathrm{mg} / \mathrm{dm}^{3}$. According to Emine and Yasar (2006) the increase recorded in adsorption of $\mathrm{Cr}$ (VI) ions was as a result of more SPP which provide availability of binding sites and contact time. Singh et al., (2015), noted that higher bed height in column implies increase in the amount of adsorbent pore spaces available to accommodate the adsorbate in the solution and this consequently decreases the solute concentration. As the bed height increases, the gradient of the breakthrough curve decreases and thus, the extension of the mass transfer zone. The values obtained indicated that the maximum column capacity $\left(\mathrm{q}_{\text {total }}\right)$ and removal percentage increased from 6.088 - $6.170 \mathrm{mg}$ and 84.5 - 85.7\% respectively (Table 1). Similar work has been reported by Chikara et al., (2010); Malkoc and Nuhoglu, (2006).

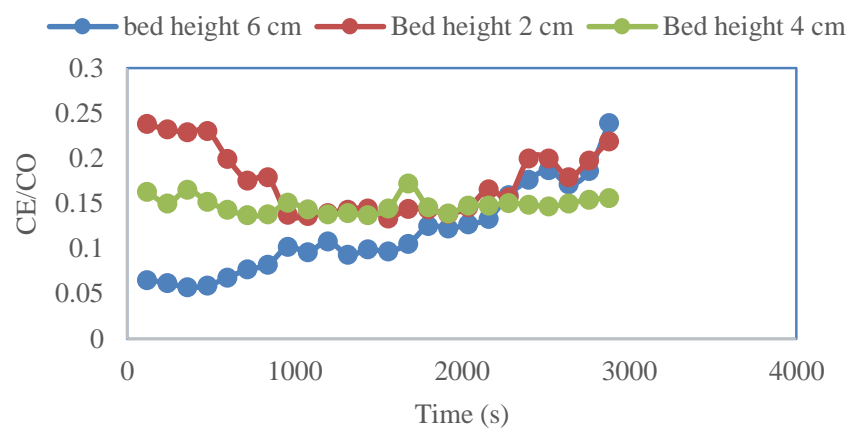

Figure 5a: Breakthrough curve for the adsorption of $\mathrm{Cr}$ (VI) ions on acid modified SPP at varying bed heights of flowrate at $0.5 \mathrm{~cm}^{3} / \mathrm{min}$ and initial metal concentration of $5 \mathrm{mg} / \mathrm{dm}^{3}$.

\section{A.3 Effect of flow rate}

Adsorption of Cr (VI) ions onto acid modified SPP was studied by varying the flow rate $\left(0.5 \mathrm{~cm}^{3} / \mathrm{min}, 1.5 \mathrm{~cm}^{3} / \mathrm{min}\right.$ and $2.0 \mathrm{~cm}^{3} / \mathrm{min}$ ) at a fixed bed height of $6 \mathrm{~cm}$ and constant influent concentration of $5 \mathrm{mg} / \mathrm{dm}^{3}$. From the results obtained, it can be observed that with increasing flow rate the percentage 
of $\mathrm{Cr}(\mathrm{VI})$ ions ion adsorbed decreases from $85.9-69.5 \%$ and invariably the total mass of $\mathrm{Cr}(\mathrm{VI})$ ions adsorbed increased from $6.1704-17.8098$ making the uptake to also increase. This was as a result of inadequate residence time necessary for the complete interaction of $\mathrm{Cr}(\mathrm{VI})$ ions and SPP in the column. Furthermore, there is diffusion limitations of the $\mathrm{Cr}$ (VI) ions into the pores of the acid modified SPP at higher flow rates (Abdul et al., 2015). From this indication, the column will perform better at a lower flow rate (Emine and Yasar, 2006).

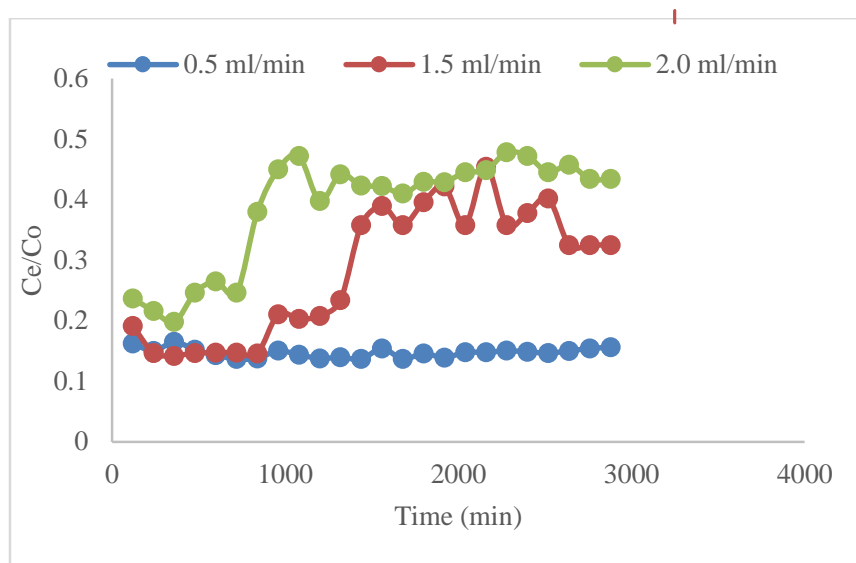

Figure 5b: Breakthrough curve for $\mathrm{Cr}$ (VI) ions adsorption onto SPP at varying flow rates of $6 \mathrm{~cm}$ bed height and metal concentration of $5 \mathbf{~ m g} / \mathbf{d m 3}$.

\section{A.4 Effect of Initial Concentration}

The initial concentration of $\mathrm{Cr}$ (VI) ions charged into the column was varied at 5,15 , and $30 \mathrm{mg} / \mathrm{dm}^{3}$ at a constant flow rate of $0.5 \mathrm{~cm}^{3} / \mathrm{min}$ and fixed bed height of $6 \mathrm{~cm}$. The high metal ions in the solution resulted in an increase in total adsorbed metal capacity and metal uptake increased from $6.1704-37.8047 \mathrm{mg} / \mathrm{g}$ and $0.4007-2.4548 \mathrm{mg}$. The high concentration gradient of $\mathrm{Cr}$ (VI) ions ion on the SPP and the $\mathrm{Cr}$ (VI) ions ion in the solution served as the driving force that accelerate the adsorption process. Molecules from the region of higher concentration (solution) tends to move faster to the region of lower concentration of $\mathrm{Cr}$ (VI) ions (SPP surface) until equilibrium is established. Thus, the higher driving force (concentration gradient) the better the column efficiency (Chikara et al., 2010; Malkoc and Nuhoglu, 2006).

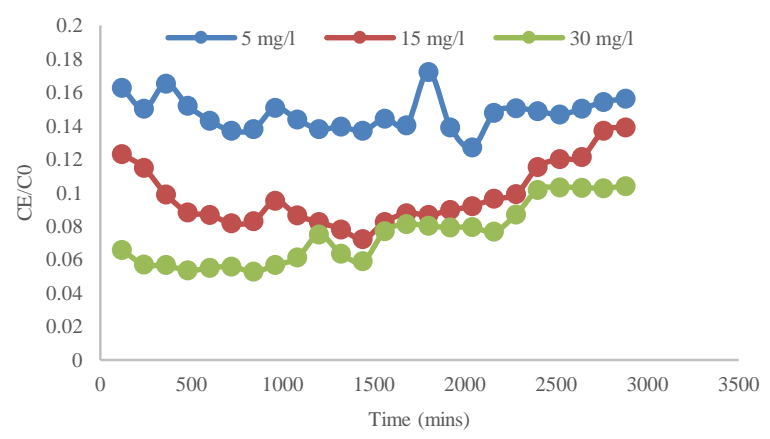

Figure 5c: Breakthrough curve for $\mathrm{Cr}$ (VI) ions adsorption onto SPP at varying concentrations of $0.5 \mathrm{~cm} 3 / \mathrm{min}$ flowrate and bed height of $6 \mathrm{~cm}$.

\section{A.5 Kinetic models}

In this study, Adam-Bohart, Yoon-Nelson and Bed Service Time are the empirical models used for the evaluation and correlation of the experimental data.

\section{A.5.1) Yoon Nelson model}

Yoon Nelson model was applied to the experimental data obtained to investigate the breakthrough behavior of chromium (VI) adsorption on acid modified SPP. This model use the parameter $\tau$, which signifies time taken for the effluent $\mathrm{Cr}$ (VI) ions concentration (Ct) to be half of the initial concentration $\left(\mathrm{C}_{\mathrm{o}} / 2\right)$. The model is expressed as Equation (1).

$$
\frac{C_{t}}{C_{o}-C_{t}}=\exp \left(k_{Y N} \tau-t_{0.5} k_{Y N}\right.
$$

where $k_{Y N}\left(\mathrm{dm}^{3} / \mathrm{min}\right)$ is the rate constant, $t_{0.5}(\mathrm{~min})$ is the time required for half the total $\mathrm{Cr}$ (VI) ions in the influent solution to breakthrough.

The values of $\tau$ and $k_{Y N}$ were determined from the intercept and slope of the linear plot of $\left.\ln \left[\frac{C_{t}}{C_{o}-C_{t}}\right)\right]$ against sampling time (mins). where $\mathrm{q}_{\mathrm{o}}=\mathrm{C}_{\mathrm{o}} \Theta \tau$ : given that $\Theta$ is the solute flow rate. The values of $\mathrm{k}_{\mathrm{YN}}, \mathrm{t}$, and $\mathrm{q}_{\mathrm{o}}$ were obtained and are as listed in Table 2. The Yoon Nelson's rate velocity constant, $k_{Y N}$, decreased with increase in bed height and flow rate, but increased with subsequent increase in initial concentration (Nwabanne and Igbokwe, 2012). There was an increase in $\tau$ as bed height increased and decreased as flow rate and initial concentration increased, this result is in agreement with several literature, (Yahaya et al. (2011); Yahya and Odigure, 2015).

Table 2: Yoon-Nelson model constants for the adsorption of $\mathrm{Cr}$ (VI) ions on SPP.

\begin{tabular}{ccccccc}
\hline $\mathrm{Q}\left(\mathrm{cm}^{3} / \mathrm{min}\right)$ & $\mathrm{L}(\mathrm{cm})$ & $\mathrm{Co}\left(\mathrm{mg} / \mathrm{dm}^{3}\right)$ & $\tau(\min )$ & $\mathrm{k}_{\mathrm{yn}}$ & $\mathrm{q}_{\mathrm{o}}(\mathrm{mg} / \mathrm{g})$ & $\mathrm{R}^{2}$ \\
\hline 0.5 & 2 & 5 & 5643 & 0.0005 & 14108 & 0.8194 \\
0.5 & 4 & 5 & 12818 & 0.0001 & 32045 & 0.0274 \\
0.5 & 6 & 5 & 1752300 & 0.000001 & 430750 & 0.0003 \\
1.5 & 6 & 5 & 2316 & 0.0009 & 17373 & 0.7562 \\
2.0 & 6 & 5 & 3729 & 0.0002 & 37290 & 0.1003 \\
0.5 & 6 & 15 & 29511 & 0.00008 & 221334.4 & 0.0152 \\
0.5 & 6 & 30 & 9584 & 0.0003 & 143760 & 0.4145 \\
\hline
\end{tabular}

\section{A.5.2) Adams-Bohart model}

This continuous adsorption model was established on the basis of surface reaction theory and it assumes that equilibrium is not instantaneous therefore, the rate of the sorption is proportional to the fraction of sorption capacity still remaining in the adsorbent (Pal et al., 2013). The Adams-Bohart equation is given as:

$$
\frac{C_{t}}{C_{o}}=\exp \left(k_{A B} C_{o} t-k_{A B} N_{o} \frac{Z}{U_{o}}\right.
$$

where $C_{o}, C_{t}\left(\mathrm{mg} / \mathrm{dm}^{3}\right)$ are the column's inlet (influent) and outlet (effluent) concentration of $\mathrm{Cr}$ (VI) ions ion respectively. $\mathrm{k}_{\mathrm{AB}}\left(\mathrm{dm}^{3} / \mathrm{mg} \cdot \mathrm{min}\right)$ is the kinetic constant, $\mathrm{U}(\mathrm{cm} / \mathrm{min})$ is the linear velocity often represented as the ratio of the volumetric flow rate to the column section area, $\mathrm{Z}(\mathrm{cm})$ is the bed height 
of the adsorbent in the column and $N_{o}\left(\mathrm{mg} / \mathrm{dm}^{3}\right)$ is the saturation concentration. The values of $N_{O}$ and $k_{A B}$ can be obtained from the intercept and slope of the linear plot of $\ln \left(\frac{C_{t}}{C_{o}}\right)$ against time (mins). After applying the equation to the experimental data for the breakthrough curve, the time of breakthrough was then obtained. The values of $\mathrm{N}_{\mathrm{o}}$ and $\mathrm{k}_{\mathrm{AB}}$ were calculated and presented in Table 3. From the Table 3, values of the rate constant $\mathrm{k}_{\mathrm{AB}}$ decreases and No increases as the bed height increases, but with increment in flow rate and initial concentration, there was an increase in the rate constant $\mathrm{k}_{\mathrm{AB}}$ but a decrease in $\mathrm{N}_{\mathrm{o}}$. This is due to the saturation of adsorbent's active sites which is in agreement with the result reported by Saadi et al. (2013) and Sekhula et al. (2012).

Table 3: Adam-Bohart model constants for the adsorption of $\mathrm{Cr}$ (VI) ions on SPP.

\begin{tabular}{cccccc}
\hline $\begin{array}{c}\mathrm{Q} \\
\left(\mathrm{dm}^{3} / \mathrm{min}\right)\end{array}$ & $\mathrm{Z}(\mathrm{cm})$ & $\begin{array}{c}\mathrm{Co} \\
\left(\mathrm{mg} / \mathrm{cm}^{3}\right.\end{array}$ & $\begin{array}{c}\mathrm{N}_{\mathrm{o}} \\
(\mathrm{mg} / \mathrm{dm} 3)\end{array}$ & $\begin{array}{c}k_{A B} \\
\left(\mathrm{dm}^{3} / \mathrm{min} . \mathrm{g}\right)\end{array}$ & $\mathrm{R}^{2}$ \\
\hline 0.5 & 2 & 5 & 33.99 & 0.00008 & 0.8233 \\
0.5 & 4 & 5 & 37.34 & 0.00002 & 0.0273 \\
0.5 & 6 & 5 & 3028.44 & 0.0000002 & 0.0003 \\
1.5 & 6 & 5 & 16.89 & 0.00012 & 0.7726 \\
2.0 & 6 & 5 & 73.30 & 0.0002 & 0.0932 \\
0.5 & 6 & 15 & 146.94 & 0.0000053 & 0.0195 \\
0.5 & 6 & 30 & 92.65 & 0.00001 & 0.4130 \\
\hline
\end{tabular}

\section{A.5.3) Bed-Depth Service Time (BDST) model}

This model was simplified from the Adam-Bohart model, which states that bed height $(\mathrm{Z})$ of a column is a function of service time ( $\mathrm{t}$ ) and the influent concentration. The equation is expressed as Equation 3.

$$
t=\frac{N_{o} Z}{C_{o} U_{o}}-\frac{1}{K_{a} C_{o}} \ln \left(\frac{C_{o}}{C_{t}}-\right)
$$

The column service time is the time taken to reach a certain percentage removal at each bed height (Mohan and Sreelakshmi, 2008). The plot of service time against bed height at a flow rate of $0.5 \mathrm{~cm}^{3} / \mathrm{min}$ (Figure 6) was linear $\left(\mathrm{R}^{2}\right.$ $=0.9643$ ) indicating BDST model correlated with the experimental data.

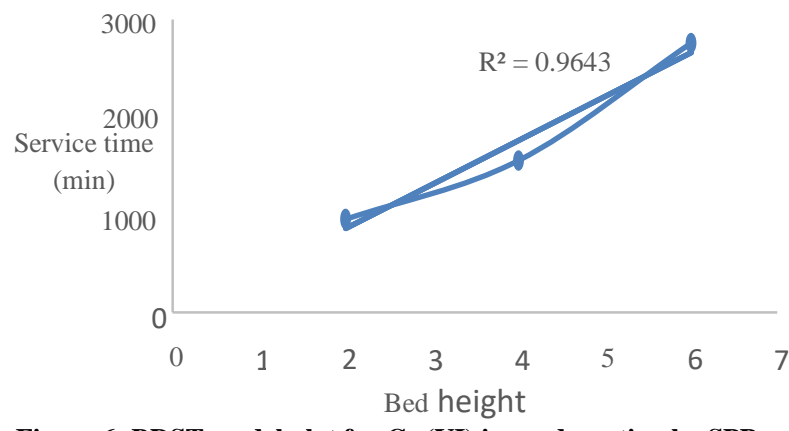

Figure 6: BDST model plot for $\mathrm{Cr}$ (VI) ions adsorption by SPP (flow rate $=0.5 \mathrm{~cm}^{3} / \mathrm{min}$ and initial concentration $=5.0 \mathrm{mg} / \mathrm{dm}^{3}$ )

The bed adsorption capacity, $\mathrm{N}_{\mathrm{o}}$, in BDST model is determined from the slope of the plot of service time, $t$, against the bed height, $\mathrm{Z}$, where the influent concentration $\mathrm{C}_{\mathrm{o}}$ and linear velocity of solution though the column $\mathrm{U}_{\mathrm{o}}$ is assumed to be constant during the column operation. The bed capacity, $\mathrm{N}_{\mathrm{o}}$, throughout the adsorption process was changing with time and thus used to predict the performance of the bed, if there was a change in the initial solute concentration, $C_{0}$ to a new value of solute concentration. As the bed height increases, the mass transfer zone also increases and thus, allowing the adsorbate molecules enough time to diffuse deeper into the adsorbent (Malkoc and Nuhoglu, 2006).

The rate constant, $\mathrm{K}_{\mathrm{a}}$, calculated from the intercept of BDST plot, indicates the rate of $\mathrm{Cr}$ (VI) ions ion transfer from the solution to the surface of SPP (Vijayaraghavan et al., 2005). $\mathrm{N}_{\mathrm{o}}$ and $\mathrm{K}_{\mathrm{a}}$ were calculated to be $4.259 \mathrm{mg} / \mathrm{dm}^{3}$ and 0.01045 $\mathrm{dm}^{3} / \mathrm{mgmin}$ respectively. The BDST model parameters can be useful to scale up the process for other flow rates without further experimental run.

\section{B. Comparison with other Adsorbents}

Table 4: Comparison of agricultural wastes adsorption capacity in the removal of $\mathrm{Cr}$ (VI) ions with other low-cost adsorbents.

\begin{tabular}{llll}
\hline Metal & Low-cost adsorbent & $\begin{array}{c}\mathrm{Q} \\
(\mathrm{mg} / \mathrm{g})\end{array}$ & \multicolumn{1}{c}{ References } \\
\hline Cr (VI) & Acid modified sweet & 2.45 & This study \\
& $\begin{array}{l}\text { potatoe peel, SPP } \\
\text { Soy hulls }\end{array}$ & 7.286 & Blanes et al., 2016 \\
& Date Pits & 1.853 & Albadarin et al., 2013 \\
& Tea Waste & 2.074 & Albadarin et al., 2013 \\
& Almond shell & 3.40 & Pehlivan and Atun, 2008 \\
& Walnut shell & 2.28 & Park et al., 2008 \\
& Groundnuts & 5.88 & Agarwal et al., 2006 \\
\hline
\end{tabular}

The adsorption capacity obtained for the modified SPP in the removal of $\mathrm{Cr}(\mathrm{VI})$ are given on Table 4. Although, the value extracted was low in comparison with other biosorbents studied, the study has demonstrated its potentials which could serve as a database for further study.

\section{CONCLUSIONS}

This research work has the following conclusions:

a) Use of acid modified sweet potato peels as a potential adsorbent for the removal $\mathrm{Cr}$ (VI) ions from aqueous solution in a fixed bed continuous system has been demonstrated.

b) The effect of flow rate, bed height and initial metal ions concentration influenced the amount of $\mathrm{Cr}$ (VI) ions adsorbed and determines the breakthrough time. The column efficiency increased as the bed height and initial metal ions concentration increased but decreased as the flow rate increases.

c) Morphological study of SPP using SEM-EDAX observed changes on the surface of SPP before and after adsorption process and the appearance of $\mathrm{Cr}$ (VI) ions, showed that the surface morphology of SPP is favourable for the binding of the $\mathrm{Cr}$ (VI) ions ion. 
d) FT-IR spectroscopy analysis indicated that the carboxylic groups, carbonyl and hydroxyl groups were responsible for the adsorption of the $\mathrm{Cr}$ (VI) ions from the effluents.

e) Column kinetics models were applied to evaluate the experimental data. The models adequately described the adsorption of $\mathrm{Cr}$ (VI) ions ion on the acid modified SPP with BDST model having the best fit with the experimental data with high regression correlation coefficients, $\mathrm{R}^{2}$, value of $96.43 \%$.

f) The bed capacity and rate constant were 4.259 $\mathrm{mg} / \mathrm{dm}^{3}$ and $0.01045 \mathrm{dm}^{3} / \mathrm{mgmin}$ respectively.

g) The various results indicated that sweet potatoes peel can be used as a biosorbent for the adsorption of $\mathrm{Cr}$ (VI) ions.

\section{REFERENCES}

Abdul, S. A.; L.A. Manaf and N. S. Kumar. (2015). Equilibrium Studies and Dynamic Behavior of Cadmium Adsorption by Palm Oil Boiler Mill Fly Ash (POFA) as a Natural Low-Cost Adsorbent. Desalination and Water Treatment, 54(7): 1956-1968.

Agarwal, G.S.; H.K. Bhuptawat and S. Chaudhari. (2006). Biosorption of Aqueous Chromium (VI) by Tamarindus Indica Seeds. Bioresour. Technol. 97 (2006): 949-956.

Ahmad, M.; S. Ahmed, B.L. Swami and S. Ikram. (2015). Adsorption of Heavy Metal Ions: Role of Chitosan and Cellulose for Water Treatment. Int. J. Pharmacognosy, 2(6): 280-89.

Ahmad, M. and Haydar, S. (2016). Evaluation of a Newly Developed Biosorbent using Packed Bed Column for Possible Application in the Treatment of Industrial Effluents for Removal of Cadmium Ions. Journal of the Taiwan Institute of Chemical Engineers, 62:122-131.

Albadarin, A.B.; C. Mangwandi, G.M. Walker, S.J. Allen, M.N.M. Ahmad, M. Khraisheh. (2013). Influence of Solution Chemistry on Cr (VI) Reduction and Complexatin onto Date/Tea-Waste Biomaterials. J. Environ. Manag. 114 (2013): 190-201.

Alok, M.; A. Rais and H. Imran. (2016). Poly (Methyl Methacrylate)-Grafted Alginate/Fe3O4 Nanocomposite: Synthesis and its Application for the Removal of Heavy Metal Ions. Desalination and Water Treatment. 57(42): 1982019833.

Amosa, M.K.; S. J. Mohammed, F. R. A. Ma'an, N. J. Dzun and A. M Suleyman. (2015). A Two-Step Optimization and Statistical Analysis of COD Reduction from Bio-treated POME using Empty Fruit Bunch Based Activated Carbon Produced from Pyrolysis. Water Qual. Expo Health, 7:603616.

Blanes, P. S.; M. E. Bordoni, J. C. Gonza'lez, S. I. Garcı'a, A. M. Atria, L. F. Sala and S. E. Bellu. (2016). Application of Soy Hull Biomass in Removal of Cr (VI) from Contaminated Waters. Kinetic, Thermodynamic and
Continuous Sorption Studies. Journal of Environmental Chemical Engineering, 4:516-526.

Chikara, S.; A. Hooda, L. Rana and R. Dhankar. (2010). Chromium (VI) Biosorption by Immobilized Aspergillus Niger in Continuous Flow System with Special Reference to FTIR Analysis. Journal Environmental Biology, 31(5): 561-566.

Cozzolino D.; S. Degner and J. Eglinton. (2014). A Review on the Role of Vibrational Spectroscopy as an Analytical Method to Measure Starch Biochemical and Biophysical Properties in Cereals and Tuber Foods. Foods, 3(4): 605-621.

Emine, M. and Yasar, N. (2006). Removal of Ni (II) Ions from Aqueous Solutions using Waste of Tea Factory: Adsorption on a Fixed-Bed Column. Journal of Hazardous Materials, 135(1-3): 328-336.

Farooq, U.; A. Janusz, M.A.K. Kozinski and A. Makshoof. (2010). Biosorption of Heavy Metal Ions Using Wheat Based Biosorbents - A Review of the Recent Literature. Bioresource Technology, 101 (2010): 5043-5053.

Fernanda, do N. C.; S.L. Aderval and C.A.C Antonio. (2016). Kinetics and Equilibrium of Lanthanum Biosorption by Free and Immobilized Microalgal Cells. Adsorption Science \& Technology, 35(1-2): 137-152.

Iqbal, M.; A. Saeed and I. Kahim. (2009). Characterization of Adsorptive Capacity and Investigation of Mechanism of $\mathrm{Cu}$ (II), Ni (II), and Zn (II) Adsorption of Mango Peel Waste from Constituted Metal Solution and Genius Electroplating Effluent. Separation Science and Technology, 44: 3770-3791.

John, C. (2000). Interpretation of Infrared Spectra, a Practical Approach. Encyclopaedia of Analytical Chemistry, 10815-10837.

Jones, J. B.; B. Wolf and H. A. Mills. (1991). Plant Analysis Handbook. Micro-Macro Publishing, Athens, Georgia.

Kakalanga, S. J.; B. J. Ximba and O. O. Beatrice. (2012). Screening of Agricultural Waste for $\mathrm{Ni}$ (II) Adsorption: Kinetics, Equilibrium and Thermodynamic Studies. International Journal of Physical Sciences, 7(17): $2525-2538$.

Kathryn B.; O. Patricia, K.G. Mary and A.C. Leigh. (2012). Sweet Potato Value Chain: Nigeria. Available on line at:https://evans.uw.edu/sites/default/files/p ublic/EPAR_UW_Request220_Nigeria\%20SP\%20Value $\% 2$ 0Chain\%20Final_0.pdf. Accessed on June 5, 2017.

Li, F.T.; H. Yang, Y. Zhao and R. Xu. (2007). Novel Modified Pectin for Heavy Metal Adsorption. Chinese Chemical Letters, 18: 325-328.

Lu, Y. and Liang, Q. (2013). Removal of $\mathrm{Pb}$ (II) from Vanillin Solution by Acid-Modified Cattail Biomass. BioResources.com, 8(2):2631-2640.

Malkoc, E. and Nuhoglu, Y., (2006). Removal of Ni(II) ions from Aqueous Solutions using Waste Tea Factory: Adsorption on a Fixed-Bed Column. Journal of Hazardous Material, B135 (2006):328-336. 
Mohan, S. and Sreelakshmi, G. (2006). Fixed Bed Column Study for Heavy Metal Removal using Phosphate Treated Rice Husk. Journal of Hazardous Materials, 153(1-2): 75-82.

Okoro I. A. and Abii T. (2011). Sorption Models of Cadmium (11) Ion onto Agricultural Tuber Wastes. American Journal of Scientific and Industrial Research. 2(3): 381-385

Pal, P. P.; F. Banat and A. AlShoaibi. (2013). Adsorptive Removal of Heat Stable Salt Anions from Industrial Lean Amine Solvent Using Anion Exchange Resins from Gas Sweetening Unit. Journal of Natural Gas Science and Engineering, 15:14-21.

Park, D.; S.L. Lim, Y.S. Yun and J.M. Park. (2008). Development of a New Cr (VI) Biosorbent from Agricultural Biowaste, Bioresources Technology, 99:8810-8818.

Pehlivan, E. and Altun, T. (2008). Biosorption of Chromium (VI) Ion from Aqueous Solutions using Walnut, Hazelnut and Almond Shell, J. Hazard. Mater. 155:378-384.

Podder, S.; B. Mousumi and C. Majumder. (2016). Fixed-Bed Column Study for As (III) and As (V) Removal and Recovery by Bacterial Cells Immobilized on Sawdust/MnFe2O4 Composite. Biochemical Engineering Journal, 105:114-135.

Prasad, G. and Abdullah, M.A. (2009). Biosorption of Fe (II) from Aqueous Solution using Tamarind Bark and Potato Peel Waste: Equilibrium and Kinetic Studies. Journal of Applied Sciences in Environmental Sanitation, 4(3): 273282.

Saadi, Z.; R. Saadi and R. Fazaeli. (2013). Fixed-Bed Adsorption Dynamics of $\mathrm{Pb}$ (II) Adsorption from Aqueous Solution using Nanostructured Y-alumina. Journal of Nanostructure in Chemistry (2013) 3:48.
Sekhula, M.M.; J.O. Okonkwo, C.M. Zvinowanda, N.N. Agyei and A.J. Chaudhary. (2012). Fixed Bed Column Adsorption of $\mathrm{Cu}$ (II) onto Maize Tassel-PVA Beads. Journal of Chemical Engineering \& Process Technology, 3(2): 1-5.

Shalaby, N. H.; E.M.M. Ewais, R.M. Elsaadany and A. Ahmed. (2016). Rice Husk Templated Water Treatment Sludge as Lowcost Dye and Metal Adsorbent. Egyptian Journal of Petroleum. Available online at http://dx.doi.org/10.1016/j.ejpe.2016.10.006. Accessed on June 5, 2017.

Singh, S.K.; D. Katoria, D. Mehta, and D. Sehgal (2015). Fixed Bed Column Study and Adsorption Modelling on the Adsorption of Malachite Green dye from wastewater using Acid Activated Sawdust International Journal of Advanced Research, 3 (7): 521-529

Ushakumary, E.R and Madhu, G. (2014). Studies on Zinc (II) Adsorption using Alisina Plantago Aqualiza. Journal of Clean Energy Technologies, 2(2): 112-117.

Vijayaraghavan, K.; Jegan, J. Palanivelu, K. and Velan, M. (2005). Batch and Column Removal of Copper from Aqueous Solution using a Brown Marine Alga Turbinaria Ornate. Chemical Engineering Journal, 106(2005): 177-184.

Yahaya, E.M.; I.A. Nasehir, F. P. Muhammed, S.B. Olugbenga and A.A. Mohd. (2011). Fixed-Bed Column Study for $\mathrm{Cu}$ (II) Removal from Aqueous Solutions using Rice Husk Based Activated Carbon. International Journal of Engineering and Technology, 11:186-190.

Yahya, M. D. and Odigure, J.O. (2015). Fixed Bed Column Study for $\mathrm{Pb}$ (II) Adsorption using Calcium Alginate Treated Shea Butter Husk (TSBH). In: Book of Proceeding of International Conference on Industrial Engineering and Operations Management (IEOM 2015), Dubai, UAE. ID724:1810-1818.810-1818. 